\title{
Assimilative Capacity Analysis of Air Pollutants over the Dawai Industrial Complex
}

\author{
Sarawut Thepanondh and Nittaya Jitbantoung
}

\begin{abstract}
The assimilative capacity of Dawai industrial complex, located in Mynamar has been evaluated by the AERMOD air dispersion model. Maximum emission loadings of $\mathrm{PM}-10, \mathrm{SO}_{2}$ and $\mathrm{NO}_{2}$ are calculated and presented in the unit of amount per unit of time as well as amount per area per unit of time. Assimilative capacity concentration is determined by subtract the $90 \%$ of air pollution standard with the exiting measured air concentration in the study area. Then the maximum loading is calculated using those assimilative capacity values. It is found that assimilative capacity of $\mathrm{PM-10}, \mathrm{SO}_{2}$ and $\mathrm{NO}_{2}$ in this area are0.0025, 0.0031 and $0.0075 \mathrm{~kg} / \mathrm{ha} / \mathrm{day}$, respectively. By considering the modeled results of maximum ground level concentration, it is found that dispersions of air pollutants in this study are greatly affected by complex topographical characteristic of the area.
\end{abstract}

Index Terms-Air model, assimilative capacity, Dawai industrial complex.

\section{INTRODUCTION}

At its Greenfield stage and under the Special Economic Zone Law, Dawei has been planned by the Myanmar government as a large fully-integrated industrial zone with a sustainable industrial complex and fully-supported infrastructure \& utilities. The Dawei Project includes the development of the Dawei deep seaport, industrial estate, pipeline along the road-link to Thailand, highways and railroad to Thailand. Dawei Deep Sea Port and Industrial Estate will cover an area of 205 square $\mathrm{km}^{2}$ or 50,675 acres. With the developing of industrialization in this area, it is expected that a large amount of air pollutants will be emitted in this area. In order to mitigate pollution problem, the air pollution assimilative capacity is evaluated for use as a tool for the area-based management of air pollution in this area.

Carrying capacity in context of industrialization can be defined as the "Maximum industrialization a region can sustain at maximum rate of resource consumption and waste discharge that can be sustained indefinitely in a defined region without progressively impairing the bio-productivity and ecological integrity of the region" [1], [2]. The assimilative capacity of the atmosphere determines the maximum pollutant load that can be discharged into the atmosphere without violating the best-designed use of air resources in the planning region and hence can prove to be an

Manuscript received August 14, 2013; revised September 30, 2013.

Sarawut Thepanondh is with the Department of Sanitary Engineering, Faculty of Public Health, Mahidol University, Bangkok 10400 Thailand (e-mail: sarawut.the@mahidol.ac.th).

Nittaya Jitbantoeng is with the College of Medicine and Public Health, UbonRatchathani University, UbonRatchathani 34190 Thailand (e-mail: jitbantoeng@hotmail.com). important tool in suggesting the safe hours for industrial operations [3]. In this study, assimilative capacity of $\mathrm{SO}_{2}$ and $\mathrm{NO}_{2}$ emission are estimated for the Dawai area. Results reveal the maximum emission loading of air pollutants for further managing of air pollution in the area-based manner.

\section{METHODOLOGY}

Assessment of impact to the air quality which may be occurred during the operation period of the project is carried out by consideration the emission from point/stationary sources. In this study, AERMOD model is selected for the level of air quality at various receptor sites. Predicted results are used to designate for the upper limit of air emission rate of factory, located in the industrial complex. Details of the study and evaluation are as follows:

\section{A. AERMOD Mathematical Modeling}

AERMOD model is developed by American Meteorological Society/Environmental Protection Agency Regulatory Model Improvement Committee. This program is started in 1991 with collaboration between the American Meteorological Society, AMS and the United States Environmental Protection Agency (US.EPA)[4]. AERMOD predicts concentration of ambient air quality by explaining a planetary boundary layer of about more than 100 meters during nighttime and up to 1-2 kilometers during daytime. The boundary layers are divided to the convective boundary layer (CBL) and the stable boundary layer (SBL). The CBL is a boundary layer which air mass is travelled as a result from sensible heat flux. The SBL is not received an influence from heat transfer but is resulted from friction velocity of the earth surface. AERMOD is a steady-state plume model. Dispersion of air pollution in SBL can be explained by using a vertical and horizontal Gaussian distribution. As for the CBL, horizontal distribution is explained by Gaussian equation while a vertical distribution is explained by the bi-Gaussian probability density function.

\section{B. Meteorological Data}

Meteorological characteristics of the year 2012, prepared by AERMET processor is used in this analysis. These data are used as input data for AERMOD model. Meteorological data, used in this assessment are analyzed from surface meteorological data, measured in the year 2012 from on-site meteorological observation station at Dawai area. Wind rose at the surface (10 meters) level information is as shown in Fig. 1. The upper air data are derived from Bangkok meteorological station. Decision of siting selection is based on availability and completeness of data. 

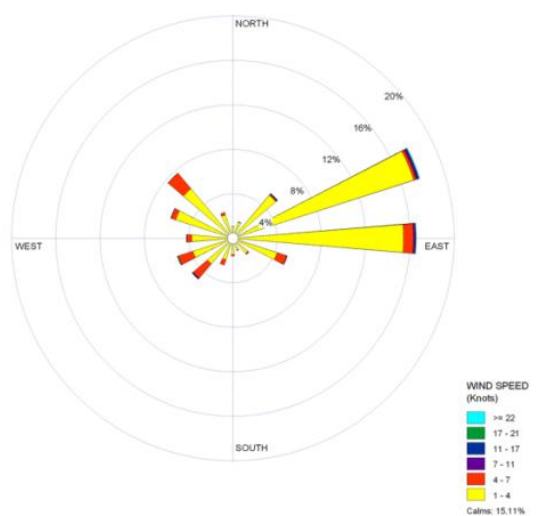

Fig. 1. Wind rose of the Dawai meteorological station in 2012.

\section{Receptor Grid}

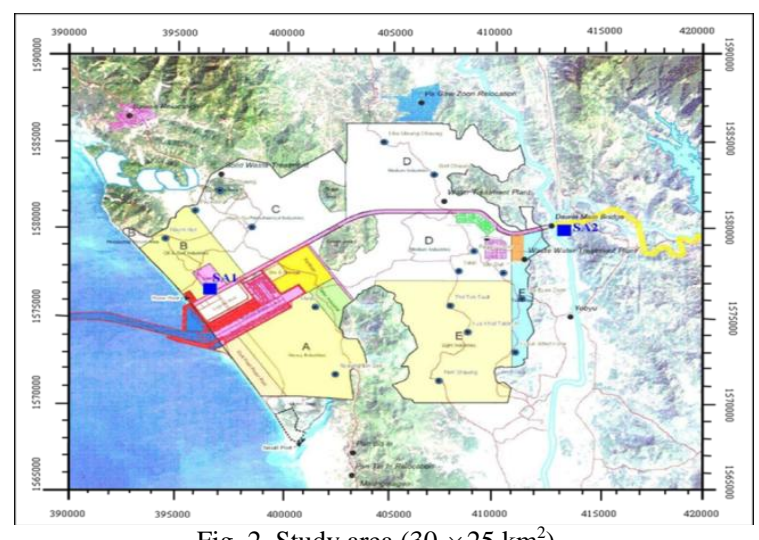

Fig. 2. Study area $\left(30 \times 25 \mathrm{~km}^{2}\right)$.
Receptor grid in this analysis is set as uniform Cartesian grid. In total, there are 3,111 grids covering the area of $30 \times$ $25 \mathrm{~km}^{2}$. Reference position is set according to UTM coordinate $(390000,156500)$ as shown in Fig. 2. Grid spacing is set as 500 meters. Discrete receptors are set taking into consideration sensitive areas which are the same places with ambient air monitoring station.

\section{Emission Source Data}

From the type of target industries, planned to be located in the Dawai deep seaport and industrial complex project, it is estimated that the type of potential air pollutants emitted in this project are PM-10, nitrogen dioxide $\left(\mathrm{NO}_{2}\right)$ and sulfur dioxide $\left(\mathrm{SO}_{2}\right)$. These pollutants are mainly emitted from stack sources.

Profile of stack characteristic of the Maptaphut Industrial Complex, located in Thailand is applied in this analysis since Maptaphut industrial complex is the biggest petrochemical complex in which there are also refineries, power plant, steel-processing, chemical and petrochemical factories which are similar with target factories in the Dawai project. Percentages of stack height of the Maptaphut industrial complex are allocated to stack height of each factory type of Dawai industrial complex.Configuration of stationary source in this analysis is set as 1 stack for every area of $1 \mathrm{~km}^{2}$. These emission profile data are used as input data for mathematical model analysis. Details are as shown in Table I.

TABLE I: EMISSION SOURCE DATA IN THIS ANALYSIS

\begin{tabular}{|c|c|c|c|c|c|c|c|c|c|c|c|}
\hline \multirow[t]{2}{*}{ Source } & \multirow[t]{2}{*}{ Emission characteristics } & \multicolumn{10}{|c|}{ Stack height $(\mathbf{m})$} \\
\hline & & 20 & 30 & 50 & 70 & 90 & 110 & 130 & 150 & 170 & 190 \\
\hline \multirow{4}{*}{$\begin{array}{l}\text { Heavy industries, } \\
\text { Zone: } \mathrm{A} \\
\left(\text { Area; } 43.81 \mathrm{~km}^{2} \text { ) }\right.\end{array}$} & No. of stack & - & - & - & - & - & 5 & 13 & 13 & - & 13 \\
\hline & Diameter $(\mathrm{m})$ & - & - & - & - & - & $\begin{array}{c}3.9 \\
0\end{array}$ & 3.65 & 6.80 & - & 6.80 \\
\hline & Stack exit temperature $(\mathrm{K})$ & - & - & - & - & - & 470 & 465 & 353 & - & 350 \\
\hline & Stack exit velocity $(\mathrm{m} / \mathrm{sec})$ & - & - & - & - & - & 6 & 40 & 18 & - & 28 \\
\hline \multirow{4}{*}{$\begin{array}{l}\text { Oil \& Gas Industrial, } \\
\text { Zone: B } \\
\text { (Area; } 13.76 \mathrm{~km}^{2} \text { ) }\end{array}$} & No. of stack & - & - & - & - & 2 & 4 & 4 & 4 & - & - \\
\hline & Diameter $(\mathrm{m})$ & - & - & - & - & 2.71 & $\begin{array}{c}3.9 \\
0\end{array}$ & 3.65 & 6.80 & - & - \\
\hline & Stack exit temperature (K) & - & - & - & - & 461 & 470 & 465 & 353 & - & - \\
\hline & Stack exit velocity $(\mathrm{m} / \mathrm{sec})$ & - & - & - & - & 22 & 6 & 40 & 18 & - & - \\
\hline \multirow{4}{*}{$\begin{array}{c}\text { Petrochemical } \\
\text { Industrial } \\
\text { Zone: } \mathrm{C} \\
\left.\text { (Area; } 28.85 \mathrm{~km}^{2}\right)\end{array}$} & No. of stack & - & - & 3 & 3 & 3 & 6 & 6 & 8 & - & - \\
\hline & Diameter(m) & - & - & 2.08 & 1.97 & 2.71 & $\begin{array}{c}3.9 \\
0\end{array}$ & 3.65 & 6.80 & - & - \\
\hline & Stack exit temperature (K) & - & - & 447 & 444 & 461 & 470 & 465 & 353 & - & - \\
\hline & Stack exit velocity $(\mathrm{m} / \mathrm{sec})$ & - & - & 13 & 11 & 22 & 6 & 40 & 18 & - & - \\
\hline \multirow{4}{*}{$\begin{array}{l}\text { Medium Industrial } \\
\text { Zone: D } \\
\text { (Area; } 65.08 \mathrm{~km}^{2} \text { ) }\end{array}$} & No. of stack & 26 & 33 & 6 & - & - & - & - & - & - & - \\
\hline & Diameter(m) & 0.89 & 1.81 & 2.08 & - & - & - & - & - & - & - \\
\hline & Stack exit temperature (K) & 514 & 424 & 447 & - & - & - & - & - & - & - \\
\hline & Stack exit velocity $(\mathrm{m} / \mathrm{sec})$ & 12 & 15 & 13 & - & - & - & - & - & - & - \\
\hline \multirow{4}{*}{$\begin{array}{l}\text { Light Industrial } \\
\text { Zone: } \mathrm{E} \\
\text { (Area; } 33.07 \mathrm{~km}^{2} \text { ) }\end{array}$} & No. of stack & 17 & 16 & - & - & - & - & - & - & - & - \\
\hline & Diameter $(\mathrm{m})$ & 0.89 & 1.81 & - & - & - & - & - & - & - & - \\
\hline & Stack exit temperature (K) & 514 & 424 & - & - & - & - & - & - & - & - \\
\hline & Stack exit velocity $(\mathrm{m} / \mathrm{sec})$ & 12 & 15 & - & - & - & - & - & - & - & - \\
\hline
\end{tabular}




\section{RESULTS AND DiSCUSSIONS}

\section{A. Existing Condition Study}

Atmospheric assimilative capacity in this study is carried out by considering the worst case scenario taking into calculation the maximum concentration of measured ambient air concentration from existing monitoring at VIP resident at ITD camp (A1 station) and at Doot Loot temple (A2 station) as background concentrations. The World Bank and the World Health Organization (WHO) air quality guideline are used as ceiling limit for ambient air quality in this analysis. It is found that, level of air pollutants, measured data during 2-5 December 2012 are lower than those ambient air quality guideline. Therefore, the assimilative capacity is determinedas a difference between guideline values and the measured ambient air concentrations. As for conservative purpose, this study use $90 \%$ of the guideline values as reference values in this analysis. Details are as shown in Table II

TABLE II: ASSIMILATIVE CAPACITY OF AMBIENT AIR CONCENTRATION IN THE STUDY AREA

\begin{tabular}{|l|c|c|c|}
\hline \multirow{2}{*}{\multicolumn{1}{|c|}{ Description }} & \multicolumn{3}{c|}{ Concentration $\left(\mu \mathrm{g} / \mathbf{m}^{\mathbf{3}}\right)$} \\
\cline { 2 - 4 } & $\begin{array}{c}\text { PM-10 } \\
\text { Avg. 24 hr. }\end{array}$ & $\begin{array}{c}\text { NO }_{2} \\
\text { Avg. 1 hr. }\end{array}$ & $\begin{array}{c}\text { SO }_{2} \\
\text { Avg. 24 } \\
\text { hr. }\end{array}$ \\
\hline $\begin{array}{l}\text { Ambient Air Quality } \\
\text { Standards }\end{array}$ & $150^{1 /}$ & $200^{2 /}$ & $150^{1 /}$ \\
\hline $\begin{array}{l}\text { 90\% of guideline values } \\
\text { (Safety Factor = 10\%) }\end{array}$ & 135 & 180 & 135 \\
\hline $\begin{array}{l}\text { Maximum concentration of } \\
\text { measured data }\end{array}$ & $90^{3 /}$ & $13^{3 /}$ & $6^{3 /}$ \\
\hline Assimilative capacity & $\mathbf{4 5}$ & $\mathbf{1 6 7}$ & $\mathbf{1 2 9}$ \\
\hline
\end{tabular}

Remark:1: [5]; 2: [6]; 3: Maximum ground level concentration, measured during 2-5 December 2012.

\section{B. Estimated Result during Operation Phase}

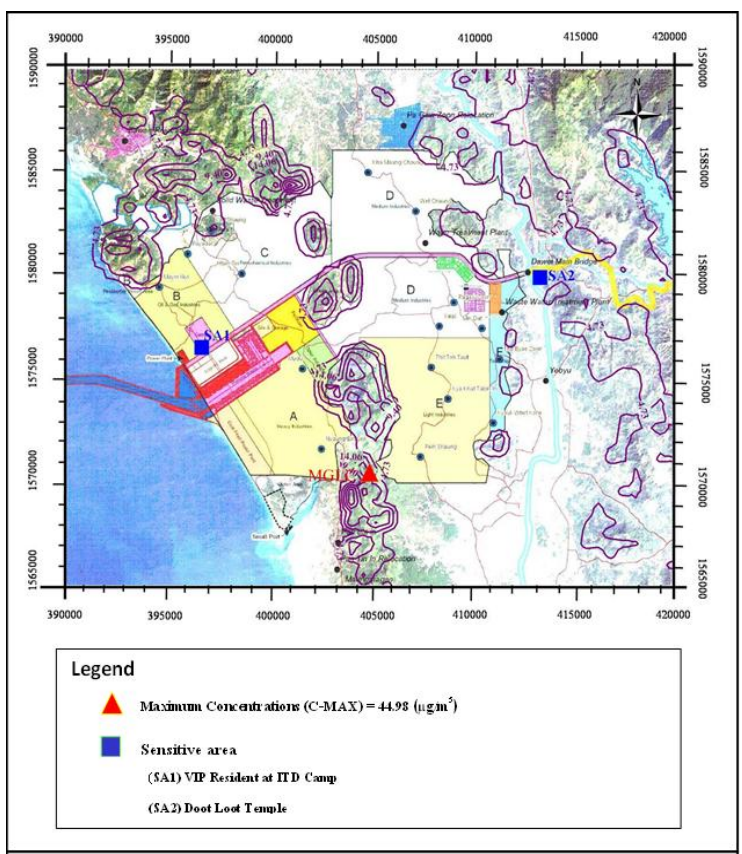

Fig. 3. Isopleth of PM-10 concentration (24hr).

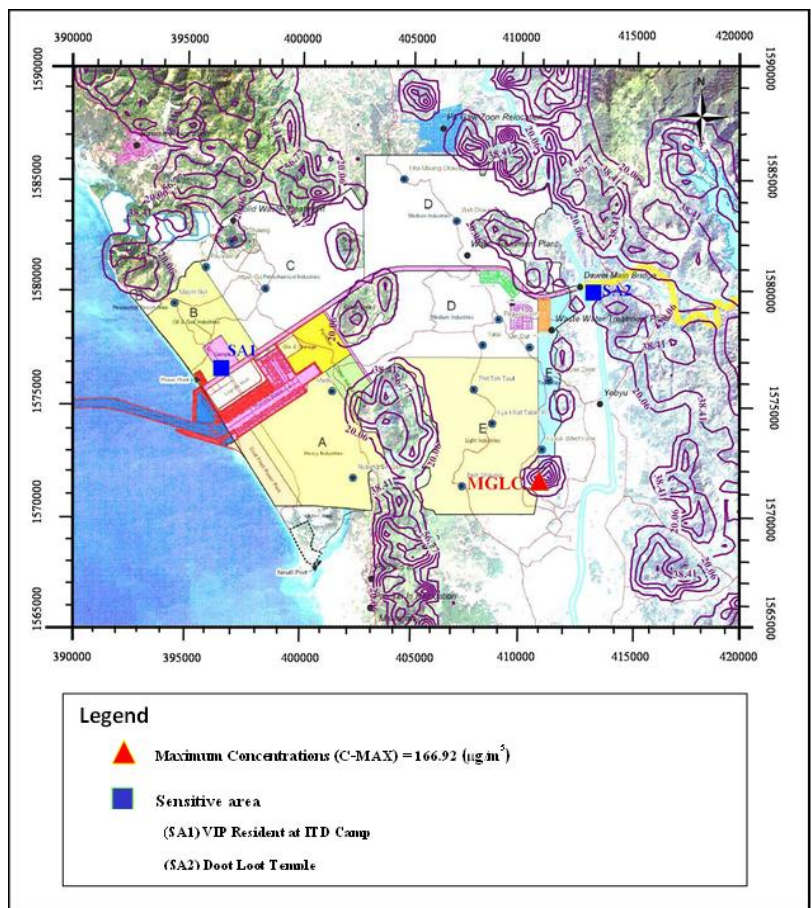

Fig. 4. Isopleth of $\mathrm{NO}_{2}$ concentration (1 hr average).



Fig. 5. Isopleth of $\mathrm{SO}_{2}$ concentration (24 hr average).

The calculated assimilative capacity of ambient air concentration is used in the air pollution modeling analysis. Trial and error method is employed by varying the emission of stack emissions in order to achieve these values. Results from AERMOD analysis are emission rate and ambient ground level concentration at receptor points as shown in Table III. The isopleths of air pollutants concentration are as illustrated in Fig. 3-Fig. 5. Maximum ground level concentrations of predicted and measured data are combined together for evaluation of emission loading for each pollutant.

The maximum ground level concentrations are predicted in the mountain area due to complex terrain characteristic of the study area. It should be noted from the analysis that the 
predicted concentrationsof air pollutants at both receptors (SA1 \& SA2) are much lower than the air quality guidelines. The places where the maximum ground level concentrations are predicted are the mountain area in the south (for $\mathrm{SO}_{2}$ and PM-10) and southeast direction (for $\mathrm{NO}_{2}$ ) of the industrial complex. It should be noted that the low assimilative capacity of PM-10 (45 ug/m $\mathrm{m}^{3}$ for $24 \mathrm{hr}$ standard) in this analysis is occurred from high background concentration from an actual measurement $\left(90 \mathrm{ug} / \mathrm{m}^{3}\right)$ which accounted for about $60 \%$ of the PM-10 ambient air quality standard $\left(150 \mathrm{ug} / \mathrm{m}^{3}\right)$.

TABLE III: EMISSION RATE AND AMBIENT AIR CONCENTRATION AT RECEPTOR POINT

\begin{tabular}{|c|c|}
\hline $\begin{array}{l}\text { PM-10: } \\
\text { Air quality guideline }\left(\mu \mathrm{g} / \mathrm{m}^{3}\right)\end{array}$ & $\begin{array}{c}150^{1 /} \\
45^{3 /}\end{array}$ \\
\hline Emission loading & $\begin{array}{c}0.577 \mathrm{~g} / \mathrm{s} \\
0.0025 \\
\mathrm{~kg} / \mathrm{ha} / \mathrm{day}\end{array}$ \\
\hline $\begin{array}{l}\text { Ambient air concentration }\left(\mathrm{ug} / \mathrm{m}^{3}\right) \\
\text { - (SA1) VIP Resident at ITD Camp } \\
\text { - (SA2) Doot Loot Temple }\end{array}$ & $\begin{array}{l}2.40 \\
2.93\end{array}$ \\
\hline $\begin{array}{l}\text { Maximum ground level concentration } \\
\left(\mathrm{ug} / \mathrm{m}^{3}\right)\end{array}$ & 44.98 \\
\hline $\begin{array}{l}\mathrm{NO}_{2}: \\
\text { Air quality guideline }\left(\mu \mathrm{g} / \mathrm{m}^{3}\right)\end{array}$ & $\begin{array}{l}200^{2 /} \\
167^{3 /}\end{array}$ \\
\hline Emission loading & $\begin{array}{c}0.642 \mathrm{~g} / \mathrm{s} \\
0.0031 \\
\mathrm{~kg} / \mathrm{ha} / \mathrm{day}\end{array}$ \\
\hline $\begin{array}{l}\text { Ambient air concentration }\left(\mathrm{ug} / \mathrm{m}^{3}\right) \\
\text { - (SA1) VIP Resident at ITD Camp } \\
\text { - (SA2) Doot Loot Temple }\end{array}$ & $\begin{array}{l}7.92 \\
8.42\end{array}$ \\
\hline $\begin{array}{l}\text { Maximum ground level concentration } \\
\left(\mathrm{ug} / \mathrm{m}^{3}\right)\end{array}$ & 166.92 \\
\hline $\begin{array}{l}\mathrm{SO}_{2}: \\
\text { Air quality guideline }\left(\mu \mathrm{g} / \mathrm{m}^{3}\right)\end{array}$ & $\begin{array}{l}150^{1 /} \\
129^{2 /}\end{array}$ \\
\hline Emission loading & $\begin{array}{c}1.654 \mathrm{~g} / \mathrm{s} \\
0.0075 \\
\mathrm{~kg} / \mathrm{ha} / \mathrm{day}\end{array}$ \\
\hline $\begin{array}{l}\text { Ambient air concentration }\left(\mathrm{ug} / \mathrm{m}^{3}\right) \\
\text { - (SA1) VIP Resident at ITD Camp } \\
\text { - (SA2) Doot Loot Temple }\end{array}$ & $\begin{array}{l}6.89 \\
4.59\end{array}$ \\
\hline $\begin{array}{l}\text { Maximum ground level concentration } \\
\left(\mathrm{ug} / \mathrm{m}^{3}\right)\end{array}$ & 128.93 \\
\hline
\end{tabular}

Remark:1: [5]; 2: [6]; 3:Assimilative capacity values from Table II.

\section{CONCLUSIONS}

Dispersion of air pollutant of this study was carried out by using the AERMOD dispersion model. Parameters of air pollutant in this analysis are $\mathrm{PM}-10, \mathrm{NO}_{2}$ and $\mathrm{SO}_{2}$. The assimilative capacity value of these air pollutants are estimated taking into account the ambient air quality guideline values, designated by the World Bank and WHO together with the maximum ground level concentration of air pollutant from the measurement. As for conservative purpose, the $90 \%$ of ambient air quality guideline are employed in the analysis.It is found that assimilative capacity of PM-10, $\mathrm{SO}_{2}$ and $\mathrm{NO}_{2}$ in this area are 0.0025, 0.0031 and $0.0075 \mathrm{~kg} / \mathrm{ha} /$ day, respectively. Low carrying capacity of air pollutants in this analysis is resulted from the effect of complex topographical characteristic of the area. Due to complex terrain of the study area, it was found that the maximum ground level concentration of air pollutants from the modeled results were located in the mountain area as illustrate in Fig. 3-Fig. 5. It is expected that the impact caused by air pollution in this area will be as the minimum to moderate level if the industrial complex can control the emission amount of air pollution according to this calculated assimilative capacity values.

\section{ACKNOWLEDGMENT}

The authors would like to express their appreciation to the Pollution Control Department of Thailand and the Thai Meteorological Department for providing data for the analysis. The study was partially supported by the China Medical Board (CMB), Faculty of Public Health and Faculty of Graduate Studies, Mahidol University, Bangkok, Thailand.

\section{REFERENCES}

[1] S. P. Singal, "Assimilative capacity studies in an industrial area," Indian Journal of Air Pollution Control, vol. 9, pp. 62-72, 2009.

[2] M. Shaikh, "SPM assimilative capacity assessment of MundraTaluka," Indian Journal of Air Pollution Control, vol. 10, no. 2, pp. 68-77. 2010.

[3] P. Goyal, T. V. B. P. S. R. Krishna, and S. Anand, "Assimilative capacity and dispersion of pollutants in Delhi," in Proc. Indian Natnsci Acad., 2003, pp. 775-784.

[4] S. G. Perry, A. J. Cimorelli, R. J. Paine, R. W. Brode, J. C. Weil, A. Venkatram, R. B. Wilson, R. F. Lee, and W. D. Petersm, "AERMOD: a dispersion model for industrial source applications.part II: model performance against 17 field study databases," Journal of Applied Meteorology, vol. 44, pp. 694-708. 2005.

[5] Environmental, Health, and Safety Guidelines, World Bank Group, 2007, pp. 3-17.

[6] M. Krzyzanowski and A. Cohen, "Update of WHO air quality guidelines," Journal of Air Quality and Atmospheric Health, vol. 1, pp. 7-13.

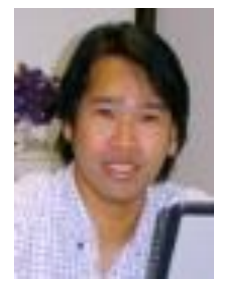

Sarawut Thepanondh has Ph.D. in Atmospheric Science from Monash University, Australia. His major field of study is in air pollution. He has earned his Ph.D. degree in 2003.

$\mathrm{He}$ is now working as a fulltime faculty member in the Department of Sanitary engineering, Faculty of Public Health at Mahidol University in Thailand. 